\title{
Simulation Modeling of the Relative Influence of the Benefits of Defense Capability Strategies on the Security of States
}

\author{
Vasyl Porokhnya \\ Classical private university \\ Zaporizhzhia, Ukraine \\ vprhnp76@gmail.com
}

\author{
Oleksandr Ostapenko \\ Military Institute of Taras Shevchenko \\ National University of Kyiv \\ Kyiv, Ukraine \\ ap080011@gmail.com
}

\begin{abstract}
Throughout its existence, the Ukrainian state has always suffered from political, economic and military harassment by neighboring states from ancient times to the present day. Whether its geographical location, which determines the center of Europe, or ineffective leadership, has always forced Ukraine to uphold its legitimate interests, territorial integrity and independence. Under such conditions, the Armed Forces of Ukraine (the Armed Forces) are the key to protecting the territorial integrity and inviolability of Ukraine entrusted to them by the Constitution of the state. Ukraine has a relative backwardness in the economic defense capabilities, which needs to be addressed by raising the indicators of macroeconomic development, innovation and economic potential, social health of the population of the state, and the support of the Armed Forces of Ukraine, by the state. The estimation of the defense capability of the states of Ukraine, Poland, Russia and Turkey is made on the basis of the developed methodological approach to the overall representation of the health of the economies of the states and their defense capabilities using the method of constructing petal diagrams with the definition of their effective areas, which became indicators of economic status and defense capability. The results of the assessment of the developed and applied indices of defense capabilities of the states of Ukraine, Poland, Russia and Turkey indicate some deviations of the ratings of the states according to the MCI military potential index in comparison with the GFI global fire strength indexes and the Credit Suisse (CS) institute for the states Ukraine and Poland. According to GFI, the global fire strength index is inferior to Poland, and the MCI military capability index is the opposite. This suggests that these states have almost one level of defense, if not take into account that Poland is a member of NATO. As to the economic status of the defense capability of Turkey and Russia, Russia is ahead of and has a second world level after the United States. But they also have significant economic problems that, in the long run, give Ukraine, with proper planning of defense capabilities and the availability of significant intellectual capital, to reach their level and to ensure the inviolability of the borders from possible encroachment.
\end{abstract}

Keywords: economic status, defense capability, military potential index, global fire strength index, neighbor states, neural network, defense strategy.

\section{INTRODUCTION}

The arms race, whose next wave began to emerge in the world, is the most difficult stage for the economy of each state, Table I. In fact, this is a test of the strength of economic development for its innovation and competitiveness, not only in the field of defense but also in industries that shape the potential of the economy. The question arises where to raise funds for their own innovative product, or where to borrow them from available sources in order not to aggravate the economic health of the state.

TABLE I. LINK TO THE NEXT WAVE OF WEAPONS RACE (ARMAMENT COSTS)

\begin{tabular}{|c|c|c|c|c|c|c|}
\hline \multirow{4}{*}{$\begin{array}{c}2018 \\
\text { \$billion / } \\
\text { \%increase }\end{array}$} & Ukraine & Poland & Russia & Turkey & France & Total \\
\hline & $4.8 / 21$ & $11.6 / 8.9$ & 61.4 & $19 / 24$ & 63.8 & \multirow{3}{*}{1822} \\
\hline & India & $\begin{array}{c}\text { Saudi } \\
\text { Arabia }\end{array}$ & China & USA & NATO & \\
\hline & 66.5 & 67.6 & $\begin{array}{l}250 / \\
5\end{array}$ & $\begin{array}{l}649 / 4 \\
.6\end{array}$ & 100 & \\
\hline
\end{tabular}

\section{ANALYSIS OF THE RECENT RESEARCHES}

A significant contribution to strategic planning and solving national security problems lies in the conceptual studies and works of Gorbulin V. and Kachinsky A. [1,3] The works of Bogdanovich V., Semenchenko A. are devoted to studying the methods of formalizing strategic planning in the field of state administration ensuring the national security of the state [2]. An analytical note by Reznikova O., Tsyukalo V. "Formation of the system of strategic planning and forecasting in the sphere of national security of Ukraine" is of system interest [4,5]. Charles J. Hitch illuminated a list of the most typical decisions to be made for security and protection [6]. In Ukraine, the algorithm of the defense industry reform, as a way from the form to the content, for the first time was presented by Gritsenko A., in 2006.

\section{AN Unsolved PART OF THE GENERAL PROBLEM}

The question is whether the economy of such states as Ukraine, Belarus, Poland, Turkey can protect itself from Russia, a country with significant economic and military potential? The answer we will look for in this study.

The aim of the study is to provide a comparative analysis of indicators of macroeconomic development of states, the economic potential of states, the social health of the population of the states and support of the armed forces by the state to assess their economic and military potential.

\section{Presentation of the Main Research Material}

Let's consider the most common indicators of the state of the economy, which are directly related to the potential of the economy and have a relative influence on the level of 
security and defense capability. We divide them into groups of influence and use statistical data of economies of the most powerful four states - neighbors of Ukraine: Ukraine, Poland, Russia, Turkey. Summary data in the tab. II-V for groups of indicators.

If we reduce all the indicators into a single table, then we can construct a methodological approach to the overall representation of the health of the economies of the states using the method of constructing petal diagrams with the definition of their effective areas, which will become indicators of economic status. This is important for a general assessment of the economies of the states, which results will be put into the development of strategic directions for the development of the armed forces.

But it is important for us, apart from the general presentation of the results of the study, to have a comparative analysis of the importance of each group of indicators for each state and also with the definition of their effective areas, which will become indicators of importance. Therefore, we will consider step-by-step research direction, from the grouping of indicators to their generalization. The indicators and indicators of the groups include the following, on the basis of which we will perform a comparative analysis:

Indicators of macroeconomic development, table II [7]:

GDP; Import / Export; Exports of goods and services in\% of GDP; Added value in manufacturing in \% of GDP ; Added value in the manufacturing industry in the current rate of price growth; Household consumption expenditure in $\%$ of GDP; Gross capital accumulation in $\%$ of GDP; Market capitalization of companies in\% of GDP; GDP per capita; Government's net debt in\% of GDP; Net outflow of foreign direct investment in $\%$ of GDP; Net inflow of foreign direct investment in\% of GDP; Total production of primary energy quadrillion Btu / increment; Consumption of primary energy; Net energy imports as a share of energy use.

Indices of innovation-economic Potential of the State, Table III: World Competitiveness Index; Corruption Perceptions Index; Stock market index, USD; Food production index; Ecological efficiency index; Human Development Index, score; Consumer price index; Prosperity index, score; Official exchange rate.

The indices are composed of a large part of the characteristics that reflect the processes of forming the economic potential of the state. So the World Competitiveness Index brings together 12 indicators: Quality of Institutions; Infrastructure; Macroeconomic Stability; Health and elementary education; Higher education and training; The efficiency of the market of goods and services; Labor market efficiency; the financial market development; Technological development; The size of the domestic market; The competitiveness of companies; Innovative potential. The Human Development Index is comprised of three indicators: Expected Lifespan; Level of literacy of the population of the country; The standard of living, estimated through the GNI per person.

Table III shows comparative characteristics of the economies of states according to the criterion of the economic potential of the states. Indicators of the innovativeeconomic potential of the states indicate that intellectual capital is in accordance with the potential of economic development. Indices of social health of population, table IV: Population growth rates; Labor force participation rate, \%; Health expenditures per capita, \$; Education expenditures in\% of GDP; Renewable Internal Freshwater Resources per capita; $\mathrm{CO} 2$ emissions per capita; Unemployment rate, \%; The property rate (i.e. had income of 1.9 dollars a day); Inflation rate, consumer prices \%; Life expectancy; Population ages 65 and above (\% of total); Crime index (per 100 people).

TABLE II. DATA ON INDICATORS AND INDICATORS OF MACROECONOMIC DEVELOPMENT OF STATES [7]

\begin{tabular}{|c|c|c|c|c|c|}
\hline $\begin{array}{l}\text { Name of the } \\
\text { indicator }\end{array}$ & $\begin{array}{l}\text { Maxim } \\
\text { um-the } \\
\text { critical } \\
\text { value }\end{array}$ & $\begin{array}{c}\text { Ukrain } \\
\text { e }\end{array}$ & Poland & Russia & Turkey \\
\hline $\begin{array}{l}\text { GDP, billion } \\
\text { US dollars }\end{array}$ & - & 109.32 & 524.89 & 4007.83 & 849.48 \\
\hline $\begin{array}{l}\text { Import / Export, } \\
\text { US dollars }\end{array}$ & - & $\begin{array}{l}62386 / \\
53776\end{array}$ & $\begin{array}{l}261841 / \\
15.2 \% \\
283749 / \\
-5.4 \%\end{array}$ & $\begin{array}{l}326.9 \quad / \\
411\end{array}$ & $\begin{array}{l}214637 /- \\
3.8 \% \\
189714 / \\
5.49 \%\end{array}$ \\
\hline $\begin{array}{l}\text { Exports of goods } \\
\text { and services in } \% \\
\text { of GDP }\end{array}$ & $45 \%$ & $\begin{array}{l}49.3 \% / \\
-6.29 \%\end{array}$ & $\begin{array}{l}52.3 \% / \\
5.53 \%\end{array}$ & $\begin{array}{l}26.5 \% / \\
-10.31 \%\end{array}$ & $\begin{array}{l}22 \% / \\
-5.91 \%\end{array}$ \\
\hline $\begin{array}{l}\text { Added value in } \\
\text { manufacturing } \\
\text { in } \% \text { of GDP }\end{array}$ & $15 \%$ & $\begin{array}{l}14.2 \% / \\
1.25 \%\end{array}$ & $\begin{array}{l}20.4 \% / \\
2.77 \%\end{array}$ & $\begin{array}{l}222 \% / \\
1.15 \%\end{array}$ & $\begin{array}{l}182453 / \\
5.04 \%\end{array}$ \\
\hline $\begin{array}{l}\text { Added value in } \\
\text { the manufacturing } \\
\text { industry in the } \\
\text { current rate of } \\
\text { price growth }\end{array}$ & $5 \%$ & $\begin{array}{l}3.6 \% . /- \\
123.51 \\
\%\end{array}$ & $\begin{array}{l}4.3 \% / \\
-38.79 \%\end{array}$ & $\begin{array}{l}13.7 \% / \\
-0.34 \%\end{array}$ & $\begin{array}{l}3.8 \% / \\
34.94 \%\end{array}$ \\
\hline $\begin{array}{l}\text { Household } \\
\text { consumption } \\
\text { expenditure in } \% \\
\text { of GDP }\end{array}$ & $50 \%$ & $\begin{array}{l}65.3 \% / \\
-2.52 \%\end{array}$ & $\begin{array}{l}58.5 \% . / 0.1 \\
1 \%\end{array}$ & $\begin{array}{l}53.09 / 4 \\
5 \%\end{array}$ & $\begin{array}{l}59.8 \% /- \\
0.9 \%\end{array}$ \\
\hline $\begin{array}{l}\text { Gross capital } \\
\text { accumulation in } \% \\
\text { of GDP }\end{array}$ & $10 \%$ & $\begin{array}{l}20.4 \% . / \\
- \\
319.46 \\
\%\end{array}$ & $\begin{array}{l}-7.9 \% . / \\
-229.29 \%\end{array}$ & $\begin{array}{l}-1.8 /- \\
81.81 \%\end{array}$ & $\begin{array}{l}29.3 \% /- \\
1.33 \%\end{array}$ \\
\hline $\begin{array}{l}\text { Market } \\
\text { capitalization of } \\
\text { companies in\% of } \\
\text { GDP }\end{array}$ & $15 \%$ & $\begin{array}{l}+15.7 /- \\
45.02 \%\end{array}$ & $\begin{array}{l}38.4 \% . / \\
30.51 \%\end{array}$ & $\begin{array}{l}39.5 \% / \\
-18.38 \%\end{array}$ & $\begin{array}{l}26.7 \% / \\
34.42 \%\end{array}$ \\
\hline $\begin{array}{l}\text { GDP per capita. } \\
\text { USD }\end{array}$ & 500 & 2583 & 13823 & 10608 & 10512 \\
\hline $\begin{array}{l}\text { Government's net } \\
\text { debt in\% of GDP }\end{array}$ & $40 \%$ & $\begin{array}{l}75.6 \% . / \\
-6.95 \%\end{array}$ & $\begin{array}{l}51.4 \% . / \\
-5.10 \%\end{array}$ & $\begin{array}{l}17.4 \% / \\
11.28 \%\end{array}$ & $\begin{array}{l}22.7 \% / \\
-2.99 \% \\
\end{array}$ \\
\hline $\begin{array}{l}\text { Net outflow of } \\
\text { foreign direct } \\
\text { investment in\% of } \\
\text { GDP }\end{array}$ & $10 \%$ & $\begin{array}{l}0.2 \% . / \\
12.49 \%\end{array}$ & $\begin{array}{l}0.8 \% / \\
-64.65 \%\end{array}$ & $\begin{array}{l}2.4 \% / \\
41.00 \%\end{array}$ & $\begin{array}{l}0.3 \% / \\
-12.93 \%\end{array}$ \\
\hline $\begin{array}{l}\text { Net inflow of } \\
\text { foreign direct } \\
\text { investment in } \% \text { of } \\
\text { GDP }\end{array}$ & $1 \%$ & $\begin{array}{l}2.2 \% / \\
-41.32 \%\end{array}$ & $\begin{array}{l}1.2 \% . / \\
-66.38 \%\end{array}$ & $\begin{array}{l}1.8 \% / \\
-30.21 \%\end{array}$ & $\begin{array}{l}1.3 \% / \\
-17.07 \%\end{array}$ \\
\hline $\begin{array}{l}\text { Total production } \\
\text { of primary energy } \\
\text { quadrillion Btu / } \\
\text { increment }\end{array}$ & - & $\begin{array}{l}2.33 \\
\text { Btu / - } \\
20.75 \%\end{array}$ & $\begin{array}{l}2.3 \quad \text { Btu } \\
/ 0.70 \%\end{array}$ & $\begin{array}{l}55.94 \\
\text { Btu } \\
/ 1.09 \%\end{array}$ & $\begin{array}{l}1.22 \quad \text { Btu } \\
/ 11.3 \%\end{array}$ \\
\hline $\begin{array}{l}\text { Consumption of } \\
\text { primary energy }\end{array}$ & - & $\begin{array}{l}3.44 \\
\text { Btu /- } \\
13.79 \% \\
\end{array}$ & $\begin{array}{l}3.89 \text { Btu / } \\
1.30 \%\end{array}$ & $\begin{array}{l}29.63 \\
\text { Btu./ - } \\
1.56 \% \\
\end{array}$ & $\begin{array}{l}5.72 \text { Btu / } \\
8.77 \%\end{array}$ \\
\hline $\begin{array}{l}\text { Net energy } \\
\text { imports as a share } \\
\text { of energy use }\end{array}$ & $30 \%$ & $\begin{array}{l}27.2 \% / \\
5.99 \%\end{array}$ & $\begin{array}{l}28.5 \% / \\
0.55 \%\end{array}$ & $\begin{array}{l}-83.7 \% . / \\
-0.20 \%\end{array}$ & $\begin{array}{l}75.2 \% . / \\
1.35 \%\end{array}$ \\
\hline
\end{tabular}

The indices of the social health of the population actually characterize the environment in which the population of the state is, and how this environment affects their physical and economic status. Factors are related both to the ecological 
state of the territory inhabited by the population, and to the social protection of the population and its intellectual development to replenish human capital. The final indicators are those that focus on the rates of growth and life expectancy of the population.

TABLE III. INDICES OF INNOVATION-ECONOMIC POTENTIAL OF THE STATE [7]

\begin{tabular}{|c|c|c|c|c|}
\hline Indicator & Ukraine & Poland & Russia & Turkey \\
\hline The World Competitiveness Index & $4.11 / 2.75 \%$ & $4.59 / 0.66 \%$ & $4.64 / 2.88 \%$ & $4.42 / 0.68 \%$ \\
\hline The Corruption Perceptions Index & $30 / 3.45 \%$ & $60.00 /-3.23 \%$ & $29.00 / 0.0 \%$ & $40 /-2.44 \%$ \\
\hline Stock market index. USD. & $31.2 \% . / 12.07 \%$ & $50.2 \% / 1971.1 \%$ & $4.4 /-91.06 \%$ & $33.8 /-465.64 \%$ \\
\hline Ecological efficiency index & $79.69 / 25.38 \%$ & $81.26 / 8.12 \%$ & $83.52 / 24.34 \%$ & $67.68 / 7.31 \%$ \\
\hline Human Development Index, score & $0.74 /-0.67 \%$ & $0.86 / 0.35 \%$ & $0.80 /-0.12 \%$ & $0.77 / 0.39 \%$ \\
\hline Consumer price index & $235.3 / 14.4 \%$ & $109.6 / 2.08 \%$ & $168.2 / 3.68 \%$ & $175 / 11.14 \%$ \\
\hline Official exchange rate & $26.6 / 4.09 \%$ & $3.8 /-4.15 \%$ & $58.3 /-12.99 \%$ & $4.8 / 3.03 \%$ \\
\hline Crime index (per 100 people) & $4.4 /-8.98 \%$ & $0.7 / 1.37 \%$ & $11.3 /-6.84 \%$ & $4.3 / 3.37 \%$ \\
\hline
\end{tabular}

Unfortunately, Ukraine among some indicators is in a critical position. These include, first of all, the following: population growth rates; health expenditures per capita; education expenditures in \% of GDP; the property rate (i.e. had income of 1.9 dollars a day); crime index (per 100 people); life expectancy. These indicators confirm that our society and our economy have serious signs of a social disease, which deepens every year.

The comparative characteristic of the economies of the states according to the criterion of social health of the population of the state is given in table $\mathrm{V}$.

G) Indices of support of the Armed Forces by the state, tab. 5: Resources (dollars) for defense and security and their $\%$ of GDP; Import / Export Armaments (USD); The share of exports of high-tech products; Research and development expenditures in the form of a share of GDP; Export of food as a share of export of goods; Imports of food as a share of imports of goods.

TABLE IV. INDICES OF SOCIAL HEALTH OF POPULATION [7]

\begin{tabular}{|c|c|c|c|c|}
\hline Indicator & Ukraine & Poland & Russia & Turkey \\
\hline $\begin{array}{l}\text { Total / population } \\
\text { growth rates }\end{array}$ & $\begin{array}{l}44.77 / \\
-0.4 \%\end{array}$ & $\begin{array}{l}44.01 / \\
0 \%\end{array}$ & $\begin{array}{l}144.2 / \\
0.1 \%\end{array}$ & $\begin{array}{l}80.7 / \\
1.5 \%\end{array}$ \\
\hline $\begin{array}{lr}\text { Labor } & \text { force } \\
\text { participation } & \text { rate } / \%\end{array}$ & $\begin{array}{l}17.89 / \\
49.1 \%\end{array}$ & $\begin{array}{l}22.31 / \\
53.8 \%\end{array}$ & $60.2 \%$ & $45.8 \%$ \\
\hline $\begin{array}{l}\text { Health } \\
\text { expenditures per } \\
\text { capita. } \$\end{array}$ & $\begin{array}{l}125 / \\
-31.52 \%\end{array}$ & $\begin{array}{l}797 / \\
-11.08 \%\end{array}$ & $\begin{array}{l}1414 / \\
5.53 \%\end{array}$ & $\begin{array}{l}455 / \\
-13.77 \%\end{array}$ \\
\hline $\begin{array}{l}\text { Education } \\
\text { expenditures in } \% \\
\text { of GDP }\end{array}$ & $\begin{array}{l}5.87 \% / \\
-11.9 \%\end{array}$ & $\begin{array}{l}4.91 \% / \\
-0.56 \%\end{array}$ & $\begin{array}{l}3.8 \% / \\
-7.61 \%\end{array}$ & $\begin{array}{l}4.4 \% / \\
0.16 \%\end{array}$ \\
\hline $\begin{array}{l}\text { Renewable Internal } \\
\text { Freshwater } \\
\text { Resources per } \\
\text { capita }\end{array}$ & $\begin{array}{l}1229 \mathrm{M} 3 / \\
1.07 \%\end{array}$ & $\begin{array}{l}1388 \mathrm{M} 3 / \\
0 \%\end{array}$ & $\begin{array}{l}30058 \mathrm{M} 3 / \\
-0.12 \%\end{array}$ & $\begin{array}{l}2886 \mathrm{M} 3 /- \\
4.85 \%\end{array}$ \\
\hline $\begin{array}{l}\mathrm{CO} 2 \text { emissions per } \\
\text { capita }\end{array}$ & $\begin{array}{ll}5.25 & \text { T./ } \\
8.76 \% & \\
\end{array}$ & $\begin{array}{lr}7.77 & \text { T./ } \\
2.94 \% & \\
\end{array}$ & $\begin{array}{l}3.24 \mathrm{~T} . / \mathrm{-} \\
4.14 \%\end{array}$ & $\begin{array}{ll}1.22 & \text { T./ } \\
5.17 \% & \end{array}$ \\
\hline $\begin{array}{l}\text { The property rate } \\
\text { (i.e. had income } \\
\text { of } 1.9 \text { dollars } \\
\text { a day) }\end{array}$ & $0.1 \%$ & $0 \%$ & $0 \%$ & $0.2 \%$ \\
\hline $\begin{array}{l}\text { Inflation rate. } \\
\text { consumer prices } \%\end{array}$ & 14.4 & 3.7 & 6 & 11.1 \\
\hline $\begin{array}{l}\text { Unemployment } \\
\text { rate. \% }\end{array}$ & 4.9 & 5.2 & 5.2 & 11 \\
\hline $\begin{array}{l}\text { Life expectancy, } \\
\text { years }\end{array}$ & $\begin{array}{l}72.1 \\
0.21 \% \\
\end{array}$ & $\begin{array}{l}77.8 / \\
0.20 \% \\
\end{array}$ & $\begin{array}{l}71.2 / \\
0.19 \% \\
\end{array}$ & $\begin{array}{l}76 / \\
0.34 \%\end{array}$ \\
\hline $\begin{array}{l}\text { Population ages } 65 \\
\text { and above (\% of } \\
\text { total) }\end{array}$ & $\begin{array}{l}16.5 \% . / \\
1.8 \%\end{array}$ & $\begin{array}{l}16.8 \% / \\
3.56 \%\end{array}$ & $\begin{array}{l}14.2 \% / \\
2.8 \%\end{array}$ & $\begin{array}{l}13.4 / \\
1.76 \%\end{array}$ \\
\hline
\end{tabular}

The next stage in the analysis of macroeconomic development, innovation and economic growth, social health and military budget categories is summarized in the form of the resulting indicators, table VI.

Consequently, Ukraine has a very low social health index and macroeconomic development index, which affect Ukraine's overall ranking. In general, Russia and Poland are leaders. Somewhat ahead of Ukraine is Turkey, but the country's innovation and economic growth index shows that Ukraine can increase the value of other indicators. It should be noted that the dynamics of military spending in Ukraine is positive. However, the resulting indicator clearly shows that the country's economic health is a key factor affecting the development of the country's security and defense capabilities. Therefore, the level of economic development and its impact on the defense and security reform in Ukraine in comparison with other countries needs to be considered in more detail.

TABLE V. INDICES OF SUPPORT OF THE ARMED FORCES BY THE STATE [7]

\begin{tabular}{|c|c|c|c|c|}
\hline Indicator & Ukraine & Poland & Russia & Turkey \\
\hline $\begin{array}{l}\text { Resources (dollars) } \\
\text { for defense and } \\
\text { security and their \% } \\
\text { of GDP }\end{array}$ & $\begin{array}{l}3.648 \mathrm{~B} / \\
3.41\end{array}$ & $10 \mathrm{~B} / 1.96$ & $631 \mathrm{~B} / 1.19$ & $\begin{array}{l}18.19 \mathrm{~B} / \\
2.2\end{array}$ \\
\hline $\begin{array}{l}\text { Import / Export of } \\
\text { Arms (dollars). }\end{array}$ & $\begin{array}{l}18 \mathrm{M} / \\
240 \mathrm{M}\end{array}$ & $197 \mathrm{~B} / 3 \mathrm{M}$ & $\begin{array}{l}145 \mathrm{M} / \\
23 \mathrm{M}\end{array}$ & $\begin{array}{l}410 \mathrm{~B} / \\
244 \mathrm{M}\end{array}$ \\
\hline $\begin{array}{lr}\text { The share } & \text { of } \\
\text { exports of high } \\
\text { technology } \\
\text { products }\end{array}$ & $\begin{array}{l}7.3 \% / \\
11.6 \%\end{array}$ & $\begin{array}{l}8.5 \% . / \\
-3.6 \%\end{array}$ & $\begin{array}{l}10.7 \% / \\
-22 \%\end{array}$ & $\begin{array}{l}2 \% / \\
-6.03 \%\end{array}$ \\
\hline $\begin{array}{l}\text { Spending } \\
\text { research on } \\
\text { development as and } \\
\text { proportion of GDP }\end{array}$ & $\begin{array}{l}0.6 \% /- \\
4.8 \%\end{array}$ & $1 \% / 6.74 \%$ & $\begin{array}{l}1.1 \% / \\
4.0 \%\end{array}$ & $1 \% / 6.62 \%$ \\
\hline $\begin{array}{l}\text { Imports of food as a } \\
\text { share of imports of } \\
\text { goods }\end{array}$ & $\begin{array}{l}8.4 \% / \\
-12.4 \%\end{array}$ & $\begin{array}{l}8.8 \% / \\
-2.00 \%\end{array}$ & $\begin{array}{l}12.2 / \\
-7.08 \%\end{array}$ & $\begin{array}{l}5.7 \% / \\
1.88 \%\end{array}$ \\
\hline $\begin{array}{l}\text { Export of food as a } \\
\text { share of export of } \\
\text { goods }\end{array}$ & $\begin{array}{l}40.8 \% / \\
-2.5 \%\end{array}$ & $\begin{array}{l}13 \% / \\
2.86 \%\end{array}$ & $\begin{array}{l}5.7 / \\
-2.88 \%\end{array}$ & $\begin{array}{l}11 \% / \\
-7.19 \%\end{array}$ \\
\hline
\end{tabular}

Table VI shows the comparative analysis of economic growth on the basis of macroeconomic development, innovation and economic growth, social health and ensuring defense capability. 
TABLE VI. A COMPARATIVE ANALYSIS OF THE ECONOMIC GROWTH BASED ON THE MACROECONOMIC DEVELOPMENT, INNOVATION AND ECONOMIC GROWTH, SOCIAL HEALTH, AND ENSURING DEFENSE CAPABILITY

\begin{tabular}{|c|c|c|c|c|c|}
\hline States & $\begin{array}{c}\text { Index of } \\
\text { macroeconomic } \\
\text { development, } \\
\text { rating }\end{array}$ & $\begin{array}{c}\text { Index of } \\
\text { economid } \\
\text { potential } \\
\text { of the } \\
\text { state, } \\
\text { rating }\end{array}$ & $\begin{array}{c}\text { The } \\
\text { index of } \\
\text { social } \\
\text { health of } \\
\text { the } \\
\text { populati } \\
\text { on, } \\
\text { rating }\end{array}$ & $\begin{array}{c}\text { Support } \\
\text { index of } \\
\text { the } \\
\text { Armed } \\
\text { Forces } \\
\text { by the } \\
\text { state, } \\
\text { rating }\end{array}$ & $\begin{array}{c}\text { Gener } \\
\text { alized } \\
\text { index } \\
\text { rating }\end{array}$ \\
\hline Ukraine & $0.72 / 5$ & $1.28 / 3$ & $0.46 / 4$ & $0.75 / 3$ & $0.80 / 4$ \\
\hline Poland & $0.52 / 4$ & $2.45 / 1$ & $1.23 / 2$ & $0.81 / 2$ & $1.25 / 2$ \\
\hline Russia & $1.52 / 1$ & $1.22 / 4$ & $1.72 / 1$ & $0.95 / 1$ & $1.35 / 1$ \\
\hline Turkey & $1.00 / 2$ & $1.78 / 2$ & $0.71 / 3$ & $0.23 / 4$ & $0.93 / 3$ \\
\hline
\end{tabular}

The indicators of the economic status of the defense capabilities of the states included those that are directly related to the potential of the defense industrial complex (OPK). Each state has its own production and use of weapons manufactured by the defense industry. This enables not only the export of weapons, but also to replenish its own military potential. In this regard, Ukraine has sufficient potential for the innovative upgrading of armored, land, air and missile troops. Ukraine's defense industry has state-ofthe-art weapons of war technology and they are not inferior to Russia's arms, but the economic situation in Ukraine is in critical condition. In this direction, the innovation and economic potential of Poland and Turkey has considerably more problems with its own production of armaments. Therefore, they spend considerably more money on the acquisition of modern weapons compared to Ukraine. Such a situation in Ukraine requires a tight strategic program for the development of the armed forces.

An important defense capability is the export of high-tech products and the cost of research and development and education, which shape the prospect of the development of the Armed Forces and affect simultaneously the economic development of the state. Important aggregates are the indices of human development and global competitiveness, which are complemented by the well-known global firepower index (Global Firepower Index).

In general terms, the ranking of economic health indexes of the economies of the states confirms the economic situation of the states, which was obtained by the method of classification of groups of indicators of indicators for the defense and security of states. Therefore, there is a need to consider more about the weapons and military potential of each state and compare them with world indices that determine the level of combat capability of countries.

The proposed Military Capacity Index(MCI), unlike the Global Fire Strength Index, GFI, focuses more on macroeconomic indicators that directly affect development of defense capabilities and does not focus on indicators that can, in the long run, create a threat of combat capability during the war, for example: fuel to provide armored, land and airborne troops; human reserves, etc.

After receiving the results by the ISI index, we will conduct a comparative analysis with the GFI global fire strength indexes and the Credit Suisse Institute index, the data of which is given in table VII
However, the Ukrainian, Polish, Russian and Turkish defense capabilities ratings indicate some deviations in the ratings for Ukraine and Poland according to the Military Capacity Index against the Global Firepower Index and the Credit Suisse Institute Index. According to the Global Firepower Index, Ukraine is below Poland, and according to the Military Capacity Index, the ratings are the opposite. Since Poland is a NATO country, this suggests that the defense capabilities of Ukraine and Poland are almost equal. Economic growth, which directly affects the Turkey's defense capability rating and Russia's defense capabilities rating, indicates that Russia is ahead of Turkey and is second only to the United States. However, these countries also have significant economic problems, and thus Ukraine has good chances to reach their development level through proper planning of defense capabilities and available intellectual capital.

To analyze the impact of social and economic development on the country's defense capability, let's build a neural network. Based on previous justifications [8, 9], let's focus on the most likely indicators that characterize the defense capabilities of the countries: macroeconomic development index; innovation and economic growth index; social health index; the share of high-technology exports; the cost of research and development in the defense industry; index of defense spending; human development index; defense and security resources (dollars) and their percentage in GDP; arms imports/exports (dollars); number of personnel; nuclear weapons; strategic missile forces; tactical air defense missile troops.

Of course, depending on national defense strategies, these indicators have different levels of values. Based on experience, we can say that the most successful defense strategies are the following:

1. Strategy - variation of coefficients approaching the maximum range - focusing on rocket troops, air defense (missile troops).

2. Strategy - variation of coefficients mixed, above the middle of the range - focusing on submarines, aircraft carriers and rocket troops;

\section{Focusing on NATO;}

\section{Focusing on nuclear weapons and missile forces.}

Based on the peculiarities of approaches to the country's defense capability, it is possible to perform a simulation of the relative impact of the benefits of defense strategies and accordingly approach the construction of a neural network structure that provides the use of mathematical methods and models to find the dependencies between the selected indicators (Fig. 1,2).

Based on the country's defense capability, one can approach the construction of the neural network structure. The average value of social and economic development and defense capability of the country is considered as an input indicator for the neural network (Fig. 3). This average value determines the relation to the level of development of another country on the basis of training in the neural network, depending on the possible values of indicators, the status of the country with respect to each of the critical indicators, defense strategies. 
TABLE VII. THE RATING OF THE STATES ACCORDING TO THE GLOBAL FIREPOWER INDEX, ACCORDING TO THE MILITARY CAPACITY INDEX AND THE CREDIT SUISSE INSTITUTE INDEX $[7,10,11]$

\begin{tabular}{|l|l|l|l|l|l|l|}
\hline \multicolumn{1}{|c|}{ States } & $\begin{array}{c}\text { Military Capacity } \\
\text { Index }\end{array}$ & \multicolumn{1}{|c|}{$\begin{array}{c}\text { Priority by the } \\
\text { MCI }\end{array}$} & $\begin{array}{c}\text { Global Firepower } \\
\text { Index }\end{array}$ & $\begin{array}{c}\text { Priority by the } \\
\text { GFI }\end{array}$ & $\begin{array}{c}\text { Index Credit } \\
\text { Suisse, }\end{array}$ & $\begin{array}{c}\text { Priority by the } \\
\text { Credit Suisse }\end{array}$ \\
\hline Ukraine & 0.96 & 3 & $0.5363 / 29$ & 4 & 30 & 4 \\
\hline Poland & 0.70 & 4 & $0.4276 / 22$ & 3 & 17 & 3 \\
\hline Russia & 1.93 & 1 & $0.0841 / 2$ & $2 / 1$ & $2 / 1$ & $2 / 1$ \\
\hline Turkey & 1.17 & 2 & $0.2216 / 9$ & 2 & 10 & 2 \\
\hline
\end{tabular}

After conducting the neural network research, there was fixed concern of the social-economic development and national defense capability rate of one country compared to another country, see table VIII.

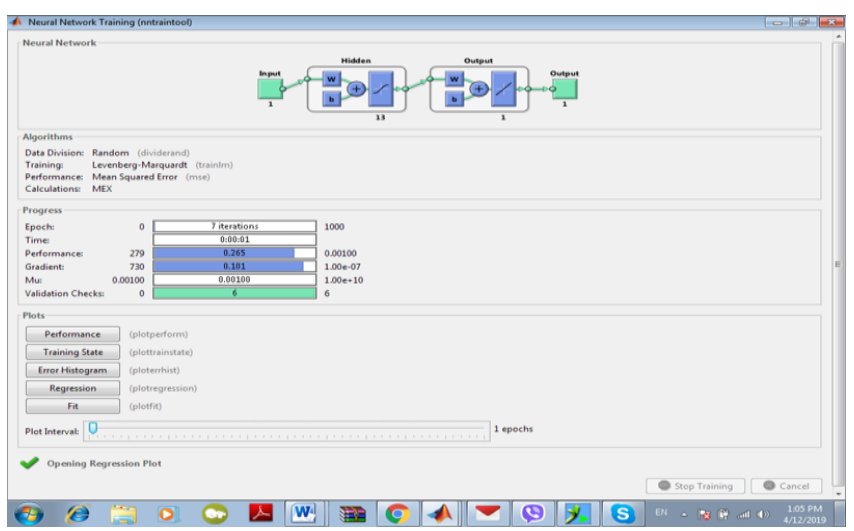

Fig. 1. Construction of the neural network structure

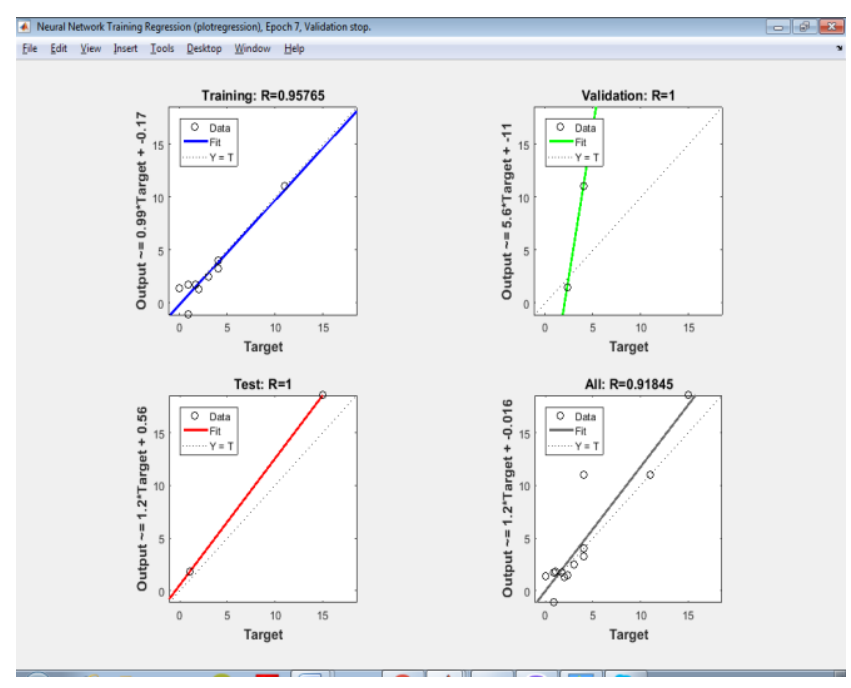

Fig. 2. Regression of connections between incoming data and objective indicators after studying in the neural network.

TABLE VIII. INDICATORS THAT CHARACTERIZE THE DEFENSE CAPABILITY OF A COUNTRY

\begin{tabular}{|c|c|c|c|c|c|c|c|}
\hline Ukraine & $\begin{array}{c}\text { S1 } \\
\text { Variation of } \\
\text { coefficients } \\
\text { approaching } \\
\text { the maximum } \\
\text { range - focusing } \\
\text { on rocket } \\
\text { troops, air } \\
\text { defense (missile } \\
\text { troops). }\end{array}$ & Poland & $\begin{array}{c}\text { S2 } \\
\text { Variation of } \\
\text { coefficients } \\
\text { mixed, above } \\
\text { the middle of } \\
\text { the range - } \\
\text { focusing on } \\
\text { submarines, } \\
\text { aircraft carriers } \\
\text { and rocket } \\
\text { troops }\end{array}$ & Russia & $\begin{array}{l}\text { Focusing } \\
\text { on NATO }\end{array}$ & Turkey & $\begin{array}{l}\text { Focusing on } \\
\text { nuclear } \\
\text { weapons and } \\
\text { missile forces }\end{array}$ \\
\hline Ukraine & - & Ukraine & 2.52 & Ukraine & 2.69 & Ukraine & 2.67 \\
\hline Poland & 7.2 & Poland & - & Poland & 2.5 & Poland & 4.61 \\
\hline Russia & 15.5 & Russia & 7.84 & Russia & - & Russia & 5.8 \\
\hline Turkey & 6.1 & Turkey & 4.26 & Turkey & 2.9 & Turkey & - \\
\hline
\end{tabular}




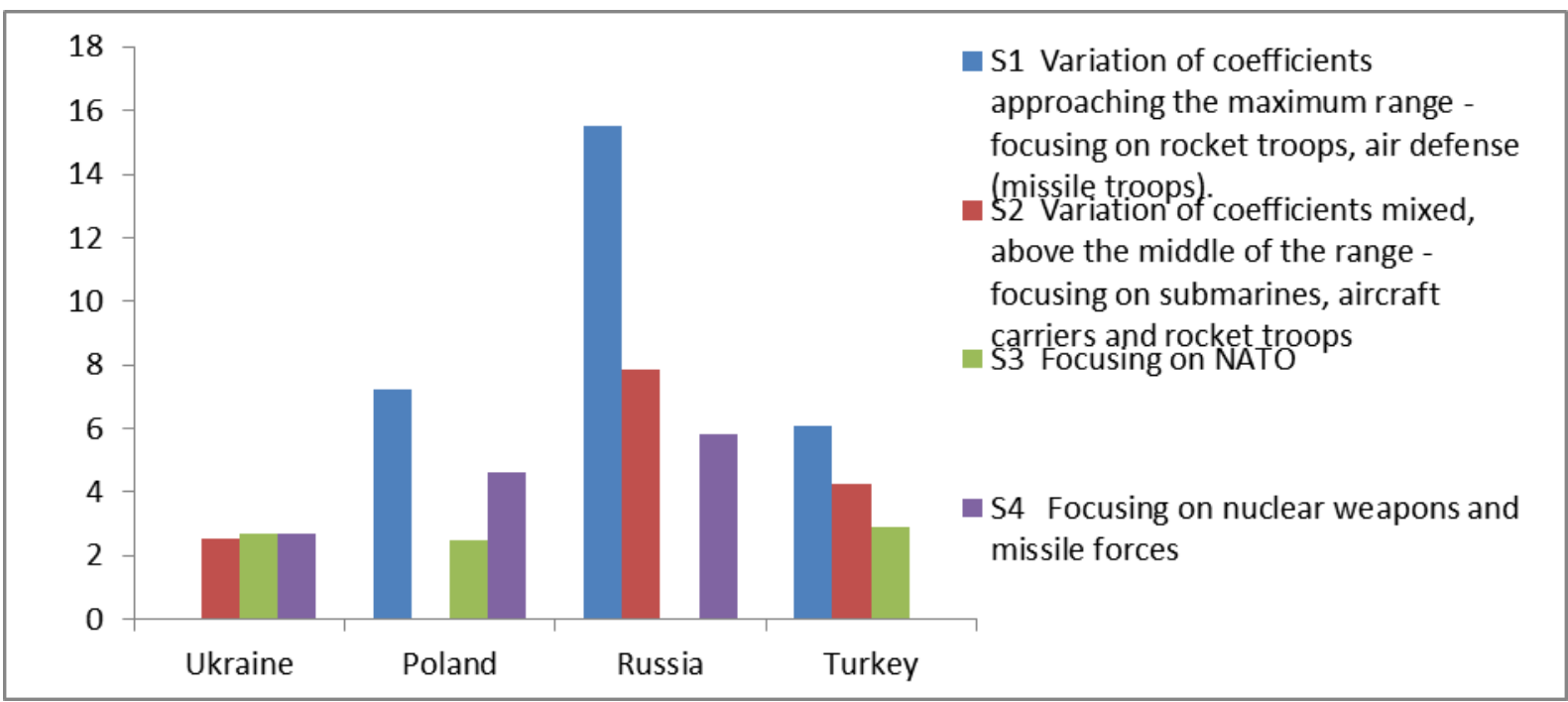

Fig. 3. Relative influence of defensive strategies advantages on the state security simulation results

On figure 3 presented results of relative influence of defensive strategies advantages on the state security simulation.

In strategic terms, every country has its own ratios of using any given strategies in completing the overall strategy. Therefore, the table allows comparing their value for every geopolitical structure, in this case - for countries, noted in the work.

Depending on the input characteristics average means, the following countries: Russia, Poland and Turkey have the highest defense capability priority for Ukraine.

Thus, for Poland these countries are: Russia, Turkey and Ukraine.

However, if compared with Russia, there are several differences in the priority list of the countries. For Russia they are: Turkey, Ukraine, and Poland.

While talking about Turkey, both Russia and Poland have greater priority for this country, than Ukraine does.

For the nonce, as the simulation results show, Ukraine has nominal development index lag, which influences notably on the general image of the national defense capability and security state.

\section{CONCLUSIONS}

During the whole period of its existence, beginning with the very ancient times and until now, Ukrainian nation have been perpetually experiencing political, economic and military oppressions from the neighboring countries. It has always been enforced to protect its legal interests, integrity and independence, resulting from either its geographical position, which marked the center of Europe, or its poor leadership. In such circumstances, the Armed Forces of Ukraine are authorized by the Constitution to acts as a key factor for sawing territorial integrity and untouchability of Ukraine.

Simulation modeling of the relative impact of the benefits of defense strategies on the security of states in the neural network shows the importance of indicators of socioeconomic development and defense capacity of the state to indicators of another state. Depending on the average value of the input characteristics for Ukraine, Russia, Poland, and Turkey, have the highest priority for defense. The main role in this process is played by the choice of the defense and security strategy of the state, depending on the availability of state security resources.

Ukraine has nominal lag in defense capability economical support. This issue should be solved by increasing macroeconomic development rates, innovationeconomic potential, national social climate and the Armed Forces of Ukraine support.

\section{REFERENCES}

[1] V.Gorbulin, Strategic planning: solving problems of national security. Kiev: NISS, 2010.

[2] V. Bogdanovich, "Method of formalization of strategic planning in the field of state management of ensuring the national security of the state", Strategic Panorama, no. 3, pp. 42-53, 2006.

[3] A. Kachinsky, Security, Threats and Risks: Scientific Concepts and Mathematical Methods. Kiev, 2003.

[4] O. Reznikova, "Formation of the system of strategic planning and forecasting in the sphere of national security of Ukraine“, 2018. [Online]. Available: http://www.niss.gov.ua/ articles/1847. Accessed on: April 24, 2019.

[5] O. Reznikova, "Ensuring the sustainability of the state and society against the terrorist threat in Ukraine and the world", Strategic priorities, no. 3 (44), pp. 23-24, 2017.

[6] Charlles J. Hitch, Decision Making For Defense. N-Y: Science, 2004

[7] World Data Atlas., 2018. [Online]. Available: https://knoema.com/atlas. Accessed on: January 29, 2019.

[8] V. Porokhnya, Intellectual Capital of Economic Growth: A Manual. Zaporozhye: KPU, 2012.

[9] V. Porokhnya, and O. Ostapenko, "Neural network and index forecasting of the strategies of development of the armed forces of Ukraine depending on their own economic opportunities and encroachments of the states of aggressors", in 8th International Conference on Monitoring, Modeling \& Management of Emergent Economy (M3E2 2019), Odessa, 2019. Available: https://doi.org/10.1051/shsconf/20196504004 (WoS).

[10] Globalfirepower, 2018. [Online]. Available: https://www.global firepower.com/countries-listing-europe.asp. Accessed on: January 20, 2019.

[11] CreditSuisse, 2018. [Online]. Available: https://www.creditsuisse.com/corporate/en/research/research-institute/publications.html. Accessed on January 28, 2019. 